\title{
A Survey of ICT Usage Across English Secondary Schools
}

Jonathan Savage BA (hons), PGCE, PhD

Institute of Education

Manchester Metropolitan University

799 Wilmslow Road

Didsbury

Manchester M20 2RR

01612472363

j.savage@mmu.ac.uk

\section{Biographical Note}

Jonathan Savage is a Reader in Education at the Institute of Education, Manchester Metropolitan University. His main research interests lie in the field of developing innovative uses of new technologies within the music curriculum.

$\mathrm{He}$ is Managing Director of UCan.tv (www.ucan.tv), a not-for-profit company that produces engaging educational software and hardware including Sound2Picture (www.sound2picture.net), Sound2Game (www.sound2game.co.uk) and Hand2Hand (www.hand2hand.co.uk). Free Moodle courses are available at www.ucan.me.uk. 


\begin{abstract}
The use of information and communication technologies (ICT) is a statutory component of the Key Stage 2 and 3 National Curricula in the United Kingdom (QCA 2008). Recent research has examined the impact of ICT on processes of music teaching and learning (Ofsted 2009, TTRB 2009). This research presents findings from a national survey of the availability and usage of ICT in music classrooms within English secondary schools. It also examined a range of issues related to the training and continuing professional development opportunities that teachers utilised to develop their skills in this area. Key findings from the research show that music education is dominated by conservative uses of ICT that reinforce traditional subject content. Rigorous strategies for the sharing of knowledge in this area are needed if wider impact is to be made on the delivery of music curriculum that exploits the broader potential of ICT to widen access and provide students with an inclusive and personalised curriculum.
\end{abstract}




\section{Introduction}

Within the United Kingdom, the use of information and communication technologies (ICT) is prescribed in the formal curriculum requirements in the primary and secondary sectors (QCA 2008). Previous curriculum orders have emphasised the application of ICT to composition activities; more recent curriculum orders have considered the application of ICT to the teaching and practice of musical performance within the classroom and other learning contexts through the 'extended' curriculum.

In the wider world, musical practices have been transformed by digital technologies. Hardly a week goes by without comment in the international press about a new technological innovation or application related to the production, reception or consumption of music in one form or another. Within the last few weeks, issues such as the establishment of an agency for navigating online copyright issues for film and musical content has been discussed (Fitzsimmons 2009), new systems to help train people to use prosthetic limbs using Guitar Hero (a music video game) have been developed (Graham 2009) and iPhone or iTouch owners can use their portable devices to play virtual pianos, drums and guitars (Apple 2009). 
The disjunction between these two worlds has been noted by many authors commenting on school-based education (Savage 2004, p.167; Cain 2004, p.217; Ofsted 2009, p.34) and higher education (Draper 2008, p.137; Jenkins et al 2007, p.129).

\section{Context}

During the past year, two major pieces of research have been published in the United Kingdom that, in varying levels of detail, have explored the application of technology to the teaching and learning of music within the school curriculum. The first of these, funded by the Training and Development Agency for Schools (TDA) and carried out by researchers at Manchester Metropolitan University, the Open University and the University of Central England (TTRB 2009), explored two key questions:

1. How do pupils learn about music using new technologies?

2. How does the introduction of new technologies affect the teacher's pedagogical approach?

An analysis of collected materials from twelve schools identified a number of interesting issues that are briefly summarised below. These twelve schools were 
spread across three Government regions across the country: the North West of England, London and the West Midlands. They covered a range of school types, including specialist schools and academies, and included schools in urban and rural locations. Further details of the research has been published by the author (Savage 2007).

Firstly, despite wide and significant cultural changes, music education within the classroom is predominantly technologically conservative. Many basic uses of ICT for music sequencing and score writing dominated teachers' work. There was a noticeable lack of integration of hardware and software with other classroom resources. In many cases, the use of ICT within the classroom makes little, if any, links to potential musical applications of ICT outside the classroom. For example, in several of the schools visited there were blanket bans on the use of mobile phones within school. However, outside school, mobile phones were one of the key technological devices that pupils used to not only listen to music, but also to collect and share audio and visual digital files often captured through the use of the mobile phone's camera.

Secondly, teachers believe they are more successful in their teaching with ICT as their pupils get older. They reported a greater degree of impact in their use of music technologies in Key Stage 4 (aged 14-16) and on post-16 courses than with younger pupils at Key Stage 3 (aged $11-14$ ). They could judge 'success' 
with music technology when it reinforced a traditional approach to music education, such as the production of a musical score or the replication of an instrumental piece through a sequencer. Teachers cited a range of possible explanations for this, including the 'overbearing' and 'rigid' structures of GCSE specifications that actively discriminate against the creative use of new technologies. At the time of the research, only one of the three United Kingdom examination bodies's approach to the use of ICT within their specification could be described as integrated or holistic. Given the extensive range of musical performance witnessed during this project, it was interesting that musical performance with any type of ICT was peculiarly absent from the reported observations. This reinforces the general perception reported by OfSTED, that school either implicitly or explicitly only tend to encourage students with traditional instrumental abilities to take further their musical studies through the GCSE qualification:

An over-emphasis on instrumental skills also contributed to lack of continuity in Key Stage 4. Music GCSE is not always seen as a natural extension to work in Key Stage 3 and the schools surveyed discouraged pupils, explicitly or implicitly, from taking GCSE if they did not have additional instrumental lessons or were not already an accomplished performer. (Ofsted 2009. p.52)

Thirdly, many teachers commented that teaching music with ICT is in some senses similar and in other senses quite different to teaching music without ICT. Music teachers work in a teaching environment that is resource-rich, containing a range of instruments and other equipment. Music lessons will contain different 
groupings of pupils. Teachers are used to managing this range of group work and giving degrees of independence to pupils. The adoption and adaptation of pieces of technology becomes just another tool in a long list of potential resources, so when new technologies become available, these models of working are easily transferable.

Finally, and in a point closely related to the previous one, as technologies permeate more deeply, pedagogical approaches needed to develop more radically. In other words, differences begin to appear when the extent or the use of technology became more extreme. For example, one school had recently acquired a recording studio with a range of specialist technology. It would have been easy for these teachers to limit access to this expensive resource to older pupils or those with an interest in music (perhaps those who have opted for further study). This was not the case. But it seemed inevitable that the teacher's role in supporting pupils' learning in this studio setting would have to develop significantly.

The second key piece of literature that has impacted the work of teachers and researchers in the United Kingdom in the last year has been Ofsted's triennial report into the state of music education across the United Kingdom (Ofsted 2009). Although this report does not focus on the use of ICT in much detail, it does provide some useful glimpses of the state of play in this area. The report is 
based on evidence from inspections of music between September 2005 and July 2008 in 84 primary and 95 secondary schools in England. It was interested to note how this report consolidates the findings of the research cited above (TTRB 2009). Two examples will be given. Firstly, note the prevailing use or impact of ICT as pupils get older in the following two extracts:

There was insufficient use of ICT in music, even though it is a statutory requirement in Key Stage 3. A detailed focus on 22 schools in the survey showed the use of ICT to be inadequate in more than half of these; only four were good or outstanding in this respect. (Ofsted 2009, p.34)

The use of information and communication technology (ICT) by the music profession continues to expand the range of music available to all pupils. Music technology encourages more boys to take a music $\mathrm{A}$ level and provides the means to enable all pupils to achieve at the highest standards, but it is underused at present, particularly in Key Stage 3. (Ofsted 2009, p.6)

Secondly, the conservative nature of music education is also highlighted, especially when compared against the use of musical ICT in the wider world and, perhaps, in pupils' experiences outside of schools,:

Music technology is changing rapidly and the schools found it difficult to develop their own resources in line with the quality of equipment which students were seeing - and sometimes using themselves - outside school. 
Consequently, ICT in school could appear dated to them. (Ofsted 2009, p. 34)

Only in the very best examples were teachers relating the work to how ICT was used in the real world so that students could explore and follow similar processes to those used professionally. (Ofsted 2009, pp.34-35)

\section{Research Design}

During 2007/08 the author was asked to conduct a survey of ICT availability and usage in high schools across the United Kingdom for a major manufacturer of music technology. This request came shortly after the data collection phase of the research project discussed above (TTRB 2009) and proved a good opportunity to reconsider some of the issues it raised within a national context. Within hindsight, it was also fortuitous that the research was conducted during a similar time period to the Ofsted triennial report (introduced above). This survey constituted the largest survey of its kind in the United Kingdom and, as such, has presented a unique opportunity to obtain a snapshot of music education with ICT in English secondary schools. The survey has provided the most extensive and comprehensive set of data. It provides many interesting points of discussion that will be presented below. 
The survey took the form of a four-page questionnaire that was posted to 3500 high schools across the United Kingdom, included as part of a free magazine from the manufacturer. Complete responses were received from 180 schools situated across the whole of the United Kingdom. Of these returns, the following breakdowns were noted in terms of participant gender and school type:

\begin{tabular}{|l|c|c|}
\hline Gender & Number & $\%$ \\
\hline Male & 104 & 58 \\
\hline Female & 75 & 41.5 \\
\hline Not stated & 1 & $<0.5$ \\
\hline
\end{tabular}

\begin{tabular}{|l|c|c|}
\hline School Type & Number & $\%$ \\
\hline Secondary 11-18 & 75 & 42 \\
\hline Secondary 11-16 & 55 & 31 \\
\hline Independent School (Mixed) & 13 & 7 \\
\hline Not stated & 12 & 7 \\
\hline Independent School (Girls) & 8 & 4 \\
\hline Secondary 13-18 & 5 & 3 \\
\hline Grammar School & 5 & 3 \\
\hline Sixth Form College & 3 & 2 \\
\hline Preparatory School (Boys) & 3 & 2 \\
\hline Independent School (Boys) & 1 & $<0.5$ \\
\hline
\end{tabular}

All questionnaires were completed by the Head of Music (sometimes referred to as the Subject Leader for Music) for the school. The questionnaire covered a range of areas including: 
Section 1: Resources

- Resources, including hardware and software;

- Confidence in the use of ICT in the classroom;

- Perceptions relating to the adequacy of the current resource level;

- Familiarity with Internet based materials;

- Effectiveness of interactive whiteboards as educational tools;

- Effectiveness of documentation as an aid to lesson planning.

Section 2: Usage

- The amount of time ICT is used with different year groups;

- Keyboards and how they are used;

- The prevalence of recording studios;

- The prevalence of electronic percussion.

Section 3: Training

- Provision of training and support needs;

- The resource base of music departments. 
Section 4: Purchasing

- Ordering and purchasing preferences;

- Perception of the manufacturer's brand.

The results of the questionnaire were collated and analysed using a range of statistical functions within Microsoft Excel.

\section{Results}

A sample of the findings from the survey will be presented below, along with a commentary of issued raised. Follow this, a concluding section will present a series of issues for future research.

Section 1: Resources

The vast majority of departments have access to computers for musical activities. PC computers dominate music classrooms (77\%). Apple's share of the whole education market is around $10 \%$, so the $15 \%$ share within music departments noted in this survey is slightly higher than expected, probably due to their niche market within the music, art and publishing sector. It was interesting to note 
differences in which platforms teachers would choose if given a free choice:

\begin{tabular}{|l|c|c|c|}
\hline \multirow{2}{*}{$\begin{array}{l}\text { Computer } \\
\text { Platform }\end{array}$} & \multicolumn{3}{|c|}{ By Preference (\%) } \\
\cline { 2 - 4 } & Yes & No & Not Stated \\
\hline PC & 53 & 44 & 3 \\
\hline Mac & 70 & 22 & 8 \\
\hline Both & 75 & 13 & 13 \\
\hline
\end{tabular}

The much higher favourable response to the provision of Apple computers (70\%) compared to PC (53\%) and the large negative preference (44\%) against the PC platform was noteworthy.

A considerable breadth of recording equipment was found within the sampled schools (see Appendix A). Having said that, it is important to note that this full array of equipment was not found in many schools. For instance, only $22 \%$ of schools have a mixing desk; 18\% have a portable recording device (minidisc, hard disk recorder or equivalent). Few schools (13.9\%) possess any kind of sound processing equipment and much of this is very outdated; only $16 \%$ of schools have any kind of electronic percussion.

Whilst many schools have seen an influx of interactive whiteboards within general classroom areas, the research found that just over one third of music classrooms now have an interactive whiteboard. This compares favourable with the Fischer Family Trust survey (conducted between 2000 and 2003) that found 
that only $4.3 \%$ of music classrooms had access to an interactive whiteboard (Fischer Family Trust 2004).

In terms of software, the survey clearly showed that Sibelius dominates music notation software in schools, with just under $85 \%$ of schools making use of this software. In a similar way, Cubase and its various derivatives has a significant majority in the music sequencing software category. Over $63 \%$ of schools use this software. Apple's Logic has a reasonable showing (13\% which almost matches the $15 \%$ of Mac computers found above).

The data showed a reliance on these two main types of software. The paucity of other responses was considerable. The next largest response after these pieces of software was for the open-source digital editor and processor Audacity (with 24 responses and a $13 \%$ coverage).

The Average Reliability/Effectiveness Rating process also provided some interesting data. The analysis discounted the ratings prescribed to pieces of software that were only mentioned once or twice. But it was interesting to note that Finale scored a higher rating that Sibelius in the music notation section (8.8 to 8.5) and Logic scored significantly higher than Cubase in the music sequencing section (8.7 to 7.4 ). The highest rated piece of software in this survey was Sound Forge (with a rating of 9.4), closely followed by Garage Band (with an 
average rating of 9.2).

The data in this section can be compared with data collected in a previous survey by the Fischer Family Trust (Fischer Family Trust 2004). This surveyed 442 music departments between 2000 and 2003 to examine which pieces of software were being used by teachers. Interestingly, teachers also rated the impact of using each piece of software using a four-point scale (Very Little, Some, Significant or Substantial). A rating of 2.5 or above indicated that around $60 \%$ of the responses rated this resource as having a significant or substantial impact upon pupils' learning:

\begin{tabular}{|l|c|c|c|}
\hline Type of Software & Number & \% & Impact \\
\hline Cubase & 186 & 42.1 & 3.3 \\
\hline Sibelius & 182 & 41.1 & 3.2 \\
\hline Cubasis & 95 & 21.5 & 3.4 \\
\hline Logic & 71 & 16.1 & 3.3 \\
\hline Dance EJay & 45 & 10.2 & 3 \\
\hline Cakewalk & 39 & 8.8 & 2.7 \\
\hline Music Ace & 32 & 7.2 & 3 \\
\hline Micro Logic & 30 & 6.8 & 3.1 \\
\hline Finale & 13 & 2.9 & 1.8 \\
\hline
\end{tabular}

The following table compares the above data from the Fischer Family Trust with the data from this survey. The Fischer Family Trust impact ratings have been adjusted to a score out of 10 in line with this survey. 


\begin{tabular}{|l|c|c|c|c|}
\hline \multirow{2}{*}{$\begin{array}{l}\text { Type of } \\
\text { Software }\end{array}$} & \multicolumn{2}{|c|}{$\%$} & \multicolumn{2}{c|}{ Impact } \\
\cline { 2 - 5 } & FFT & $\begin{array}{c}\text { Current } \\
\text { Research }\end{array}$ & FFT & $\begin{array}{c}\text { Current } \\
\text { Research }\end{array}$ \\
\hline Cubase & 42.1 & 57.2 & 8.3 & 7.4 \\
\hline Sibelius & 41.1 & 84.4 & 8 & 8.5 \\
\hline Cubasis & 21.5 & 7.8 & 8.5 & 6.2 \\
\hline Logic & 16.1 & 13.3 & 8.3 & 8.7 \\
\hline Dance EJay & 10.2 & 8.3 & 7.5 & 7.4 \\
\hline Cakewalk & 8.8 & 3.9 & 6.8 & 7.6 \\
\hline Music Ace & 7.2 & 2.8 & 7.5 & 8.4 \\
\hline Finale & 2.9 & 2.3 & 4.5 & 8.8 \\
\hline
\end{tabular}

These figures show the increase in use of Sibelius and Cubase (significant increase in the case of Sibelius) and the decrease in use of all other software since 2003. Satisfaction, reliability, effectiveness or impact ratings for Cubase have decreased over this period. Sibelius has seen an improvement in these aspects.

It is important to remember that these responses relate to teachers' observation about the impact of a particular piece of software on pupils' learning. They do not represent a thorough analysis of the effect or implications of using a particular piece of software on a pupils' learning. Whereas some studies of this type have been conducted (e.g. Folkestad 1998, Breeze 2008), further and more detailed research is needed here in order to explore educational practices with pieces of 
software such as Sibelius and Cubase.

The research found that $83 \%$ of teachers agreed or strongly agreed that they were confident in their use of music technology in the classroom. There was no significant difference between the genders of the teachers surveyed in this respect. But one should be wary of distortion here in terms of response to the questionnaire. It is likely that the more technologically aware teachers will have returned the questionnaire given the attractiveness of a discount voucher. But this was still an encouraging figure. Over half the teachers surveyed (53\%) did not feel that their department was adequately resourced.

Section 2: Usage

The questionnaire asked teachers to indicate how much time their pupils spent using ICT during Years 7 to 13:

\begin{tabular}{|c|c|}
\hline Year Group & \% (Time) \\
\hline 7 & 32 \\
\hline 8 & 36 \\
\hline 9 & 41 \\
\hline 10 & 53 \\
\hline 11 & 55 \\
\hline 12 & 57 \\
\hline
\end{tabular}


Plotted as a graph, one can see that a gradual increase in use throughout Years 7 - 10 reaches a plateau during Years $11-13$ :

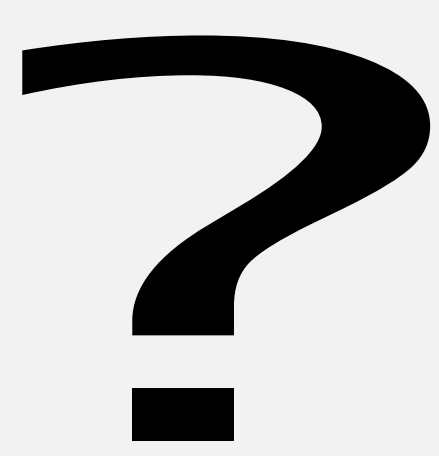

This can be interpreted in at least two ways in light of other evidence drawn from the questionnaire and wider research data.

Firstly, general uses of ICT in the Key Stage 3 curriculum could be considered the norm. Teachers will use a range of hardware and software at this level to reinforce the National Curriculum key processes performing, composing, listening, reviewing and evaluating. The move into Key Stages 4 and 5 is problematic, with much fewer pupils studying music at this level. The average figure of 43 GCSE pupils identified within our General Information section equates to 21.5 pupils in each year. However, when placed against the average 
number of pupils in each school, we find that only $4.2 \%$ of pupils elect to continue their study of music beyond Key Stage 3. This figure is lower than the reported average of $8 \%$ across the United Kingdom (Ofsted 2009, p.23). This could be read as a promising increase in recent years, but is more likely due to the fact that many schools surveyed included a range of other courses for study at Key Stage 4 and 5, including BTec qualifications and AS/A2 level qualifications in music technology which are increasing rapidly in popularity.

Recent research conducted on behalf of the Associated Boards of the Royal Schools of Music has examined trends in composition and assessment at Key Stages 3 and 4 (Fautley \& Savage 2008). Provisional analysis has shown two key trends:

1. Performance is the major curriculum component at Key Stage 3 and this changes to composition at Key Stage 4;

2. Group work approaches to performance and composition dominate the curriculum at Key Stage 3, with more individual engagement with composition at Key Stage 4.

In light of the data here, it seems certain that the increase in ICT usage in Year 10 onwards, reaching a plateau of around $55 \%$ of curriculum time, can be ascribed to the increasing use of individual activity with composition tools such as 
Sibelius or Cubase.

Secondly, the increase in use of ICT from Key Stage 4 onwards could be ascribed to the expanding array of courses being introduced at this level. These would include a range of vocational type courses that include significant elements of music technology. It seems likely this trend will continue with the recent introduction of the Creative and Media Diploma.

Both these hypotheses would need continued research to provide a more satisfactory conclusion.

The use of keyboards as a method of musical instruction was dominant. The data here is fairly self-explanatory with $87 \%$ of teachers using keyboards to teach basic piano technique and about melody, harmony and timbre. Approximately two thirds of teachers use keyboards as a MID controller of some sort that is in line with our observations about the predominance of Cubase and Sibelius outlined above.

Perhaps more surprisingly, the survey received a positive number of responses related to the provision of recording studios within music departments. $42.5 \%$ of teachers have, or are expecting to receive, a dedicated recording studio. From personal experience of visiting schools across the North West of England and in 
Northern Ireland, the author has found that these are often fairly small affairs but, nonetheless, this is a considerable innovation for schools that will need to be supported. It is in line with the increase of new courses (in particular the Creative and Media Diploma with the 14 - 19 curriculum) that contain significant elements of music production within them.

Finally, the survey noted that electronic percussion is an under-used and possibly under-valued area of music technology in schools. One reason for the lack of resource in this area could be because teachers often associate music technology with composition and recording work only. The use of ICT to support the processes of musical performance (as demanded by the new National Curriculum for Music; see QCA 2008) is in its infancy and will need a significant degree of support if it is to become a reality in the curriculum at this level.

\section{Section 3: Training}

Results in this section of the questionnaire were very disappointing. Very few teachers have received any training in the use of music technology (41.3\%). $88.4 \%$ of teachers have received less than 2 days training in the last two years.

Teachers seemed remarkably complacent in terms of looking elsewhere for 
support. $57.5 \%$ made no response when asked about whether they read any specific music or music technology magazines; $77.5 \%$ did not respond to a question that asked if they used any specific websites to develop lesson content and $32.5 \%$ were not able to cite any other sources of support for their use of music technology. It was interesting to note that 'other teachers' and the 'local authority' were the two highest rated sources of support. Given a positive spin, this indicates that teachers value the opinions of others doing the same job as themselves or their local network of teaching colleagues. More negatively, it means that teachers remain within their comfort zone and may not be challenged by new ideas about pieces of technology or how to use them in the classroom. Within this interpretation, systems of support become incestuous and knowledge self-perpetuating.

This does not paint a very encouraging picture. It reinforces the general view that teachers are finding it very difficult to obtain time away from their classes to engage in training of any type. Their lack of engagement with paper-based or web-based sources of support may also be read as a sign of teachers' general 'busyness' in the day-to-day job. It is apparent that new ideas about pieces of technology and how they might be used for teaching and learning will be difficult to get across to teachers without some kind of major cultural shift in their practices. 
In light of this, it was surprising (in one sense) to read that nearly two thirds of teachers favour 'face to face instruction in a group setting' as their preferred training option. This highlights the conservative nature of teachers' views relating to continuing professional development. It is an interesting paradox that at precisely the time when teachers are unable to obtain time for these activities their resolve for traditional instruction is still strong. Online instruction was very close to the bottom of the list of preferred options with only $21.6 \%$ of teachers citing it as their preference.

\section{Section 4: Purchasing}

The survey noted that the average departmental budget was $£ 1173.64$. A significant number of departments that did not receive any budget on an annual basis. This traditional approach had been replaced by a system of bidding for resources direct to the senior management of the school on an 'as and when' or 'need' basis. There were several positive comments about this system.

In terms of factors that influence their purchasing, it was not surprising to see that quality $(57.1 \%)$ and price $(48.1 \%)$ were the two most important factors for teachers: 


\begin{tabular}{|l|c|c|c|c|}
\hline $\begin{array}{l}\text { Key Purchasing } \\
\text { Factors (\%) }\end{array}$ & $\begin{array}{c}\text { Lowest } \\
\text { Concern }\end{array}$ & $\Rightarrow$ & $\begin{array}{c}\text { Highest } \\
\text { Concern }\end{array}$ & \\
\hline Quality & $\mathbf{1}$ & $\mathbf{2}$ & $\mathbf{3}$ & Average \\
\hline Price & 15.7 & 27.1 & 57.1 & 2.41 \\
\hline Ease of Use & 13.3 & 38.6 & 48.1 & 2.35 \\
\hline Technical Support & 35.4 & 40.4 & 24.2 & 1.89 \\
\hline Recommendation & 29 & 48.6 & 22.4 & 1.89 \\
\hline Brand & 39.3 & 43 & 17.8 & 1.79 \\
\hline
\end{tabular}

Mail order (39\%) was the preferred purchasing channel for teachers. This reflects the predominantly paper-based systems in place within schools for ordering equipment. It is important to note that mail order does not equate to local dealers. Key Suppliers listed by teachers included a number of national companies. However, local dealers were a significant purchasing channel for teachers (27.9\%), often cited because of competitive pricing, ease of returns and good after-sale support.

\section{Conclusion}

Prensky draws an interesting comparison between natives and immigrants within the digital revolution (Prensky 2001, pp.2-3). Digital natives are 'native speakers of the digital language of computers, video games and the Internet', whilst digital 
immigrants have been 'fascinated by and adopted many or most aspects of the new technology but always retain, to some degree, their 'accent', that is, their foot in the past' (ibid, pp.1-2).

Prensky's notions of the digital native or immigrant have been widely debated within educational circles. His assertion that the majority of university students are digital natives has been questioned by some (Salavuo 2008). Anecdotal evidence from the courses run by the author at the Institute of Education would also confirm this. But with respect to the issue of the use and application of ICT within music education there are wider problems. Whilst this research suggested that many teachers see themselves as competent in this area, a large number continue to struggle not just in the development of their own skills with ICT but also in applying these within curricula contexts. In particular, this research confirms that the uses and application of ICT within music education in English secondary schools is clearly conservative in nature and practice, often falling within the individual teacher's own area of expertise and experience. In this sense, it is colloquial. Where there are areas of good practice, the processes for reporting and sharing this are haphazard. The survey confirmed that many teachers find it hard to access continuing professional development opportunities that prioritise subject knowledge of this type, and that many do not favour other methods that could be utilised to provide this type of information. 
Bennet et al (2008) provides an interesting study in a parallel area to this by conducting a review of research on the current generation of university students. Whilst acknowledging that the vast majority of students today are familiar with common technologies such as the computer, the mobile phone, email and the Internet, their review finds that the application of these technologies to more advanced tasks (in which we might include the application these technologies towards the development of musical skills) is rarely evident. To this end, they wonder whether there might be as much variation in technology use within the generation defined as digital natives as those that could be found between the generation of digital natives and digital immigrants.

In presenting the findings of this research to a large group of postgraduate students engaged in a course of initial teacher education, a lively discussion ensued during which one student responded that he felt like a digital 'expat'. When questioned further on this via a follow-up online discussion, he wrote that:

I go somewhere digital, stay there and never get to know the surrounding areas. Definitely room for cyber improvement where this inexperienced little piggy is concerned. What I don't know may injure me in schools in the upcoming weeks. (Savage 2009)

This highlights another obvious danger. Digital 'expats' find comfort in their digital surroundings and may find it difficult to move on. The dangers of complacency 
are just as real for the digital native as they are for the digital immigrant.

Commenting on the challenges facing educators as they seek to implement online, social learning environments within education, Salavuo states that:

One of the biggest challenges facing institutional music education is to create supporting structures that acknowledges the existence of noninstitutional and hybrid learning environments. ... If these possibilities are ignored, there is a great risk of schools becoming increasingly irrelevant for students and the ways in which they learn and communicate. [my italics] (Salavuo 2009, pp. 121-122)

The same is true for those engaged in music education. Many teachers might describe themselves as digital immigrants. They will need to widen their understanding of what can be achieved through the creative use music technology. They will need to recognise that it has the potential to transform the nature of the music itself, as well as the how it is taught. They will need greater support with tailored materials, hardware guides, educational software, peer-topeer and 'expert' support.

For those teachers who might describe themselves as digital natives, there is another danger of complacency and colloquialism. Professional isolation is a real risk for all teachers but this can be increased through over-familiarity and reliance 
on one particular technological or pedagogical approach. The systems for distributing and sharing knowledge about the use and application of ICT within the curriculum are fragmented and often rely on personal contacts or networks. Whilst the TDA research project (TTRB 2009), Ofsted (2009) and this research have identified areas of excellent practice, the mechanisms for sharing these more widely are underdeveloped.

It is hoped that recent initiatives such as the TDA funded Teaching Music website (TDA 2009) may begin to play a constructive role in sharing good practice. But the stakes are high. Wider moves in curriculum reform seem to be moving away from subject based approaches in both the primary and secondary sectors in the United Kingdom (see QCA 2009a \& b). One can sense that music educators will need to make a much stronger case for specific curriculum time in future consultations about curriculum reform. 


\section{References}

Apple (2009) http://www.apple.com/iphone/appstore/ [last accessed 20/3/09].

Bennet, S.. Maton, K. \& Kervin, L. (2008) 'The 'Digital Natives' Debate: A critical review of the evidence'. British Journal of Educational Technology. Sept 2008.

Breeze, N. (2008) 'The Mediating Effects of ICT upon Music Composition in the Classroom'. University of Bristol. Unpublished PhD thesis.

Cain, T. (2004) 'Theory, technology and the music curriculum'. British Journal of Music Education 21:2, pp.215-221.

Draper, P. (2008) 'Music Two-Point-Zero: Music, technology and digital independence'. Journal of Music, Technology and Education 1:2-3, pp. 137-152.

Fautley, M. \& Savage, J. (2008) Assessment of Composing at Key Stages 3 and 4 in English Secondary Schools: Research report for the Associated Board of the Royal Schools of Music. Unpublished.

Fischer Family Trust (2004) 'ICT Resources Used in Music'. http:// www.fischertrust.org/downloads/ict/Report Sec Music.pdf [last accessed 20/3/09].

Fitzsimmons, C. (2009) 'Government Outlines Digital Rights Agency Proposal'. London, The Guardian. http://www.guardian.co.uk/media/2009/mar/13/ukgovernment-outlines-digital-rights-agency [last accessed 20/3/09].

Folkestad, G., Hargreaves, D. \& Lindström, B. (1998) 'Compositional Strategies in Computer-based Music-making'. British Journal of Music Education, 15:1, pp. 83-97.

Graham, F. (2009) ‘Disability No Barrier to Gaming'. London, BBC. http:// news.bbc.co.uk/1/hi/technology/7935336.stm [last accessed 20/3/09].

Jenkins, H., Purushotma. R., Clinton, K., Weigel, M \& Robison, A. J. (2007) Confronting the Challenges of Participatory Culture: Media education for the $21^{\text {st }}$ century. An occasional paper on digital media and learning. Chicago, IL: The MacArthur Foundation.

Ofsted (2009) Making More of Music, London, Ofsted. Also available from: http:// www.ofsted.gov.uk/Ofsted-home/Publications-and-research/Browse-all-by/ Documents-by-type/Thematic-reports/Making-more-of-music-an-evaluation-of- 
music-in-schools-2005-08.

Prensky, M. (2001) 'Digital Natives, Digital Immigrants' On the Horizon, NCB University Press, 9:5.

QCA (2008) 'National Curriculum for Music'. http://curriculum.qca.org.uk/keystages-3-and-4/subjects/music/index.aspx [last accessed 20/3/09].

QCA (2009a) 'Focus on the Primary Curriculum'. http://www.qca.org.uk/ qca 13584.aspx [last accessed 24/3/09].

QCA (2009b) 'Key Stages 3 \& 4'. http://curriculum.qca.org.uk/keystages-3-and-4/ index.aspx [last accessed 24/3/09].

Salavuo, M. (2008) 'Are University Students Digital Natives?' http://weblog.siba.fi/ msalavuo/2008/09/12/are-university-students-digital-natives/ [last accessed 20/3/09]

Salavuo, M. (2009) 'Social Media as an Opportunity for Pedagogial Change in Music Education'. Journal of Music, Technology and Education 1.2/3, pp.

121-136)

Savage, J. (2004) 'Working Towards a Theory for Music Technologies in the Classroom: How pupils engage with and organise sounds with new technologies'. British Journal of Music Education 22:2, pp.167-180.

Savage, J. (2007) 'Reconstructing Music Education through ICT'. Research in Education 78, p.65-77.

Savage, J. (2009) 'Are you a digital native?' http://jsavage.org.uk/? $p=202 \#$ more-202 [last accessed 20/3/09].

TDA (2009) 'Teaching Music'. http://www.teachingmusic.org.uk [last accessed 24/3/09].

TTRB (2009) 'Online Training Materials for Music and ICT (R\&RA 2:07)' http:// www.ttrb.ac.uk/ViewArticle2.aspx?Keyword=music +ict\&SearchOption=And\&SearchType=Keyword\&RefineExpand=1\&Contentld=13 401 [last accessed 20/3/09]. 


\section{Appendix A: Recording Equipment}

Free text responses to the type of recording equipment used produced the following data.

\begin{tabular}{|l|c|c|}
\hline Type of Technology & Number & $\%$ \\
\hline Mixing desk & 39 & 17.6 \\
\hline Mics & 35 & 15.8 \\
\hline Minidisc & 33 & 14.9 \\
\hline Coomber CD & 22 & 10.0 \\
\hline Fostex 16 Track & 9 & 4.1 \\
\hline Yamaha AW1600 & 8 & 3.6 \\
\hline Tascam 4 track & 7 & 3.2 \\
\hline Yamaha HD recorder & 7 & 3.2 \\
\hline Alesis HD recorder & 6 & 2.8 \\
\hline ProTools 7 + 002 rack & 5 & 2.3 \\
\hline CD recorders & 4 & 1.8 \\
\hline Tascam portastudio & 4 & 1.8 \\
\hline Boss BR-2352 & 3 & 1.4 \\
\hline Boss BR-8 & 3 & 1.4 \\
\hline DigiDesign 002 & 3 & 1.4 \\
\hline MOTU 828 & 3 & 1.4 \\
\hline Tascam MS16 & 3 & 1.4 \\
\hline Tascam USB interface & 3 & 1.4 \\
\hline Zoom 16 track HD & 3 & 1.4 \\
\hline Boss BR1180 & 2 & 0.9 \\
\hline Fostex 24 track recorder & 2 & 0.9 \\
\hline Yamaha MC1614 & 2 & 0.9 \\
\hline Zoom 4 track HD & 2 & 0.9 \\
\hline
\end{tabular}




\begin{tabular}{|l|c|c|}
\hline ADAT 24 track & 2 & 1 \\
\hline Boss BR900CD & 2 & 1 \\
\hline Coomber (unspec.) & 1 & 0.5 \\
\hline Coomber 6020 & 1 & 0.5 \\
\hline DSP audio 8x8 interface & 1 & 0.5 \\
\hline Korg 3200 & 1 & 0.5 \\
\hline Korg Multitrack & 1 & 0.5 \\
\hline Roland VS1880 & 1 & 0.5 \\
\hline Yamaha AW2816 & 1 & 0.5 \\
\hline Yamaha MD4S & 1 & 0.5 \\
\hline Yamaha MD8 & 1 & 0.5 \\
\hline
\end{tabular}




\section{Appendix B: Software}

Free text responses to the type of music software being used produced the following data. Teachers were asked to rate the reliability and effectiveness of the software out of 10 .

Score Notation Software

\begin{tabular}{|l|c|c|c|}
\hline Type of Software & Number & $\%$ & $\begin{array}{c}\text { Average Reliability/ } \\
\text { Effectiveness Rating }\end{array}$ \\
\hline $\begin{array}{l}\text { Sibelius (various } \\
\text { editions) }\end{array}$ & 152 & 84.4 & 8.5 \\
\hline $\begin{array}{l}\text { Cubase (various } \\
\text { editions) }\end{array}$ & 7 & 3.9 & 6.7 \\
\hline Finale & 5 & 2.3 & 8.8 \\
\hline Print Music & 4 & 2.2 & 7 \\
\hline Cakewalk & 3 & 1.7 & 9 \\
\hline Encore & 1 & 0.6 & 10 \\
\hline Mozart 2005 & 1 & 0.6 & 10 \\
\hline Rhapsody & 1 & 0.6 & 8 \\
\hline
\end{tabular}

Music Sequencing Software

\begin{tabular}{|l|c|c|c|}
\hline Type of Software & Number & $\%$ & $\begin{array}{c}\text { Average Reliability/ } \\
\text { Effectiveness Rating }\end{array}$ \\
\hline $\begin{array}{l}\text { Cubase (various } \\
\text { editions) }\end{array}$ & 103 & 57.2 & 7.4 \\
\hline $\begin{array}{l}\text { Logic (various } \\
\text { editions) }\end{array}$ & 24 & 13.3 & 8.7 \\
\hline $\begin{array}{l}\text { Cubasis (various } \\
\text { editions) }\end{array}$ & 14 & 7.8 & 6.2 \\
\hline $\begin{array}{l}\text { Sonar (various } \\
\text { editions) }\end{array}$ & 7 & 3.9 & 7.6 \\
\hline
\end{tabular}




\begin{tabular}{|l|l|l|l|}
\hline Garage Band & 6 & 3.3 & 9 \\
\hline Fruityloops & 2 & 1.1 & 8 \\
\hline
\end{tabular}


Audio Editing Software

\begin{tabular}{|l|c|c|c|}
\hline Type of Software & Number & $\%$ & $\begin{array}{c}\text { Average Reliabilityl } \\
\text { Effectiveness Rating }\end{array}$ \\
\hline Wave Lab & 16 & 8.9 & 7.4 \\
\hline Pro Tools & 9 & 5 & 8.1 \\
\hline SoundForge & 5 & 2.8 & 9.4 \\
\hline Garage Band & 2 & 1.1 & 8.5 \\
\hline Cool Edit Pro & 1 & 0.6 & 9 \\
\hline Audiophile & 1 & 0.6 & 8 \\
\hline
\end{tabular}

Audio Mixing Software

\begin{tabular}{|l|c|c|c|}
\hline Type of Software & Number & $\%$ & $\begin{array}{c}\text { Average Reliabilityl } \\
\text { Effectiveness Rating }\end{array}$ \\
\hline Dance Ejay & 15 & 8.3 & 7.4 \\
\hline Garageband & 5 & 2.8 & 9.2 \\
\hline Fruityloops & 2 & 1.1 & 10 \\
\hline Acid Pro & 2 & 1.1 & 8.5 \\
\hline Pro Tools & 1 & 0.6 & 10 \\
\hline EMU 0404 & 1 & 0.6 & 8 \\
\hline Spirit Folio & 1 & 0.6 & 8 \\
\hline Ableton Live & 1 & 0.6 & 7 \\
\hline
\end{tabular}

Software Synthesis

\begin{tabular}{|l|c|c|c|}
\hline Type of Software & Number & $\%$ & $\begin{array}{c}\text { Average Reliability/ } \\
\text { Effectiveness Rating }\end{array}$ \\
\hline Reason & 16 & 8.9 & 8.4 \\
\hline
\end{tabular}




\begin{tabular}{|l|c|c|c|}
\hline Fruityloops & 3 & 1.7 & 8.7 \\
\hline Halion & 3 & 1.7 & 8 \\
\hline
\end{tabular}

Freeware

\begin{tabular}{|l|c|c|c|}
\hline Type of Software & Number & $\%$ & $\begin{array}{c}\text { Average Reliabilityl } \\
\text { Effectiveness Rating }\end{array}$ \\
\hline Audacity & 24 & 13.3 & 7.6 \\
\hline Finale Notepad & 6 & 3.3 & 5.5 \\
\hline Vanbasco & 1 & 0.6 & 6 \\
\hline
\end{tabular}

Other Software

\begin{tabular}{|l|c|c|c|}
\hline Type of Software & Number & $\%$ & $\begin{array}{c}\text { Average Reliabilityl } \\
\text { Effectiveness Rating }\end{array}$ \\
\hline Acid & 6 & 3.3 & 7.5 \\
\hline Music Ace & 5 & 2.8 & 8.4 \\
\hline Music Maker & 5 & 2.8 & 8 \\
\hline Sonar Guitar Pro 4 & 3 & 1.7 & 8.3 \\
\hline Adobe Audition & 2 & 1.1 & 10 \\
\hline Aurelia & 2 & 1.1 & 8 \\
\hline Band in a Box & 2 & 1.1 & 6 \\
\hline Apple iTunes & 1 & 0.6 & 10 \\
\hline Apple Quicktime & 1 & 0.6 & 10 \\
\hline Pro & & 0.6 & 9 \\
\hline Sonar plug ins & 1 & 0.6 & 9 \\
\hline Music Suite & 1 & 0.6 & 7 \\
\hline Musition & 1 & 0.6 & \\
\hline Van Basco & 1 & & \\
\hline
\end{tabular}


